\title{
REDESCRIPTION AND DISTRIBUTIONAL RANGE EXTENSION OF A POORLY KNOWN ANCHOVY STOLEPHORUS NELSONI (ACTINOPTERYGII: CLUPEIFORMES: ENGRAULIDAE)
}

\author{
Harutaka HATA $^{1^{*}}$ and Hiroyuki MOTOMURA ${ }^{2}$ \\ ${ }^{1}$ United Graduate School of Agricultural Sciences, Kagoshima University, Kagoshima, Japan \\ ${ }^{2}$ Kagoshima University Museum, Kagoshima, Japan
}

Hata H., Motomura H. 2018. Redescription and distributional range extension of a poorly known anchovy Stolephorus nelsoni (Actinopterygii: Clupeiformes: Engraulidae). Acta Ichthyol. Piscat. 48 (4): 381-386.

Background. The poorly known anchovy Stolephorus nelsoni Wongratana, 1987 (Engraulidae), previously known only from the type specimens from Australia, is redescribed and its validity confirmed, on the basis of the holotype, paratype, and 15 additional specimens from Indonesia and Australia. Similar to Stolephorus brachycephalus Wongratana, 1983 in sharing the maxilla reaching more or less to the posterior border of opercle, a predorsal-fin scute absent and the preopercle rounded, the specific distinctiveness of $S$. nelsoni and differences between the two species have remained unclear. This study sought to confirm the validities of the two species and the distributional range of $S$. nelsoni.

Materials and methods. Seventeen and 9 specimens of S. nelsoni and S. brachycephalus, respectively, including the holotype of each, were examined morphologically, counts and proportional measurements following Hata and Motomura (2017).

Results. Comparisons of $S$. nelsoni with S. brachycephalus revealed the former to have $12-14$ (mode 13) branchiostegal rays [vs. 10-11 (11)], 15-17 branched anal fin rays [vs. 20-22 (20)] and relatively fewer gill rakers [37-43 $(39,40)$ on the first gill arch vs. 35-37 (35)]. Stolephorus nelsoni also differed from S. brachycephalus in body depth $[21.7 \%-23.7 \%$ (mean $22.6 \%$ ) of standard length vs. $18.2 \%-20.3 \%(19.1 \%)]$, anal-fin base length $[16.1 \%-19.3 \%(17.6 \%)$ vs. $21.6 \%-24.4 \%$ (23.2\%)], caudal-peduncle length $[15.7 \%-21.7 \%(18.8 \%)$ vs. $12.6 \%-$ $15.2 \%(14.1 \%)]$ and snout length $[4.5 \%-5.5 \%(5.1 \%)$ vs. $3.6 \%-4.3 \%(4.0 \%)]$.

Conclusion. The validities of both species were confirmed, Indonesian examples of $S$. nelsoni being the first known records of the species outside Australian waters.

Keywords: taxonomy, validity, morphology, distribution, Stolephorus brachycephalus

\section{INTRODUCTION}

The Nelson's anchovy, Stolephorus nelsoni Wongratana, 1987, based on four specimens from Western Australia and Queensland, Australia was originally described by Wongratana (1987), and confirmed as a valid species by Whitehead et al. (1988) and Wongratana et al. (1999). Paxton et al. (2006) listed the type specimens of $S$. nelsoni in their review of Australian engraulid fishes, there having been no additional specimens recorded. Stolephorus nelsoni is herein redescribed as a valid species, following examination of type and additional specimens from Australia and Indonesia, the latter representing the first records of the species outside Australian waters. Morphological differences between S. nelsoni and the closely related congener Stolephorus brachycephalus Wongratana, 1983 are also provided.

\section{MATERIALS AND METHODS}

Counts and proportional measurements followed Hata and Motomura (2017). All measurements were made with digital callipers to the nearest $0.1 \mathrm{~mm}$. Standard and head lengths are abbreviated as SL and HL respectively. Institutional codes follow Sabaj (2016).

\section{RESULTS}

\section{Family ENGRAULIDAE Stolephorus nelsoni Wongratana, 1987}

(Fig. 1; Tables 1,2)

Stolephorus nelsoni Wongratana 1987: 4, fig. 2 (type locality: Wallal, Eighty Mile Beach, Western Australia, Australia; paratype localities: Townsville, Queensland, Australia); Whitehead et al. 1988: 417, unnumbered figs. 
(Eighty Mile Beach, north Wallal, Western Australia and Townsville, Queensland, Australia); Wongratana et al. 1999: 1738, unnumbered figs. (Eighty Mile Beach, north Wallal, Western Australia and Townsville, Queensland, Australia); Paxton et al. 2006: 315 (Eighty Mile Beach, north Wallal, Western Australia and Townsville, Queensland, Australia). Material examined. 17 specimens, 41.2-81.5 mm SL. AMNH 57157, holotype of Stolephorus nelsoni, 71.6 mm SL, Wallal, Eighty Mile Beach, Western Australia, Australia, 15 May 1969, G. J. Nelson, W. H. Butler and D. E. Rosen; AMS IB. 3173, 59.2 mm SL, off Darwin, Northern Territory, Australia; AMS I. 26599-006, $61.7 \mathrm{~mm}$ SL, Cairns, Queensland, Australia; AMS I. 28535-001, $41.2 \mathrm{~mm}$ SL, Mackenzie Island, Queensland, Australia; NTM S. 12898-003, 2 specimens, $59.0 \mathrm{~mm} \mathrm{SL}$, north of Bowra Shoals, Fog Bay, Northern Territory, Australia, $12^{\circ} 42^{\prime} \mathrm{S}, 130^{\circ} 11^{\prime} \mathrm{E}, 20-21 \mathrm{~m}$ depth; NTM S. 13281017, 7 specimens, 59.6-81.5 mm SL, northeast of Point Charles, Beagle Gulf, Northern Territory, Australia, $12^{\circ} 11^{\prime} 27^{\prime \prime S}, \quad 130^{\circ} 24^{\prime} 27^{\prime \prime} \mathrm{E} ; \quad \mathrm{NTM}$ S. 14844-002, 2 specimens, 72.7-73.8 mm SL, estuary of Otokwa River, Irian Jaya, Indonesia, $04^{\circ} 56^{\prime} 2^{\prime \prime} \mathrm{S}, 137^{\circ} 15^{\prime} 07^{\prime \prime} \mathrm{E}, 25$ May 1996; USNM 280176, paratype of Stolephorus nelsoni, $71.6 \mathrm{~mm}$ SL, Eighty Mile Beach, Western Australia, Australia.

Diagnosis. A species of Stolephorus with the following combination of characters: gill rakers 16-19 (modally 17) in upper series on first gill arch, 20-24 (22) in lower series, 37-43 $(39,40)$ in total; gill rakers $12-14(13)$ in upper series on second gill arch, 18-22 $(20,21)$ in lower series, 30-36 (33) in total; gill rakers 9-12 (10) in upper series on third gill arch, 12-13 (12) in lower series, 2125 (23) in total; gill rakers 8-9 $(8,9)$ in upper series on fourth gill arch, 9-11 (10) in lower series, 18-20 (18) in total; prepelvic scutes 4-7 (5); branchiostegal rays 12-14 (13); pectoral fin with 13-15 rays; anal fin with three unbranched rays and 15-17 branched rays; long upper jaw, posterior tip more or less reaching posterior border of opercle; no predorsal scute; body deep, $21.1 \%$ $23.7 \% \mathrm{SL}$; anal-fin base short, $16.1 \%-19.3 \% \mathrm{SL}$; caudal peduncle long, $15.7 \%-21.7 \% \mathrm{SL}$, snout relatively long, $4.5 \%-5.5 \% \mathrm{SL}$; posterior border of preopercle convexly rounded; a pair of dark patches behind occiput without a following pair of dark lines; no black spots below eye or on lower-jaw tip.

Description. Data for holotype presented first, followed by paratype and non-type data in parentheses (if different). Counts and measurements, expressed as percentages of SL or HL, given in Tables 1 and 2.

Body compressed laterally, elongate, deepest at dorsal-fin origin. Dorsal profile of head and body slightly convex from snout tip to dorsal-fin origin, straight along dorsal-fin base. Ventral profile of head and body slightly convex from lower-jaw tip to pelvic-fin insertion, slightly convex or straight from pelvic-fin insertion to anal-fin origin, more or less straight along anal-fin base. Dorsal and ventral profiles of caudal peduncle slightly concave. Belly rounded. Anus situated just anterior to anal-fin origin. Caudal peduncle compressed; depth slightly greater than orbit diameter. Snout tip rounded; snout length less than eye diameter. Mouth large, inferior, ventral to body axis, extending backward beyond posterior margin of eye. Lower jaw slender, shorter than upper jaw. Maxilla long, its posterior tip pointed, just reaching to posterior border of opercle (beyond or just short of posterior border of opercle in some specimens). Single row of conical teeth on each jaw and palatines. Small conical teeth in patch on vomer. Small tooth

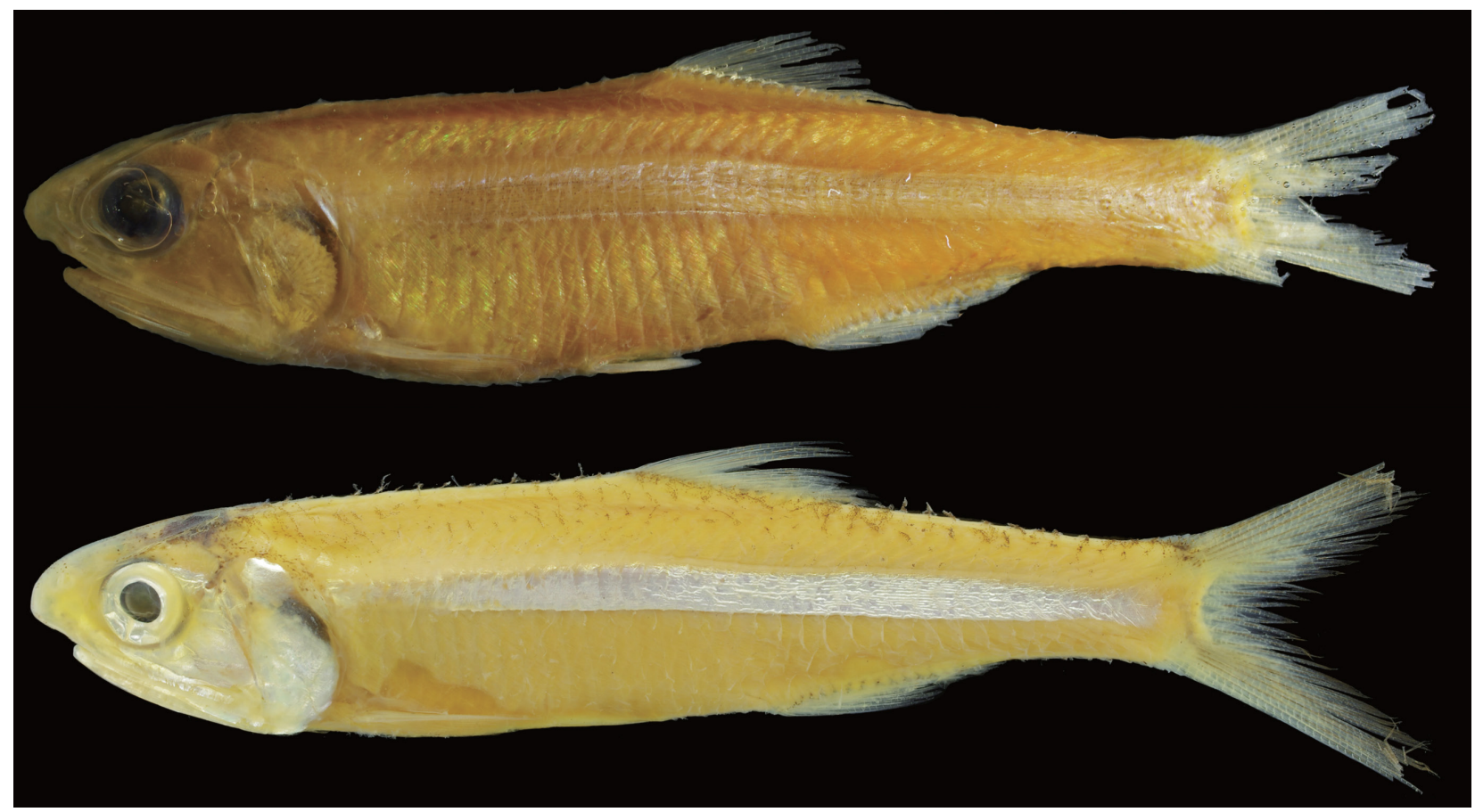

Fig. 1. Preserved specimens of Stolephorus nelsoni; upper, AMNH 57157, holotype of Stolephorus nelsoni, $71.6 \mathrm{~mm}$ SL, Western Australia, Australia; lower, NTM S. 14844-002, 72.7 mm SL, Irian Jaya, Indonesia 
patch on dorsal surface of hyoid bone. Eye large, round, covered with adipose eyelid, positioned laterally on head dorsal to horizontal through pectoral-fin insertion, visible in dorsal view. Pupil round. Orbit elliptical. Nostrils close to each other, anterior to orbit. Posterior margins of preopercle and opercle smooth. Subopercle with rounded posterior margin. Opercular membrane without serrations. Interorbital space flat. Interorbital width less than eye diameter. Pseudobranchial filaments present, length of longest filament less than eye diameter. Gill rakers long, slender, rough, visible from side of head when mouth opened. Isthmus muscle long, reaching anteriorly to posterior margin of gill membranes. Urohyal hidden by isthmus muscle (not visible without dissection). Gill membrane on each side joined distally, isthmus muscle mostly exposed (not covered by gill membrane). Scales cycloid, thin, deciduous, absent on head and fins, except for broad triangular sheath on caudal fin. Lateral line absent. Dorsal-fin origin posterior to vertical through base of last pelvic-fin ray, slightly posterior to middle of body. Dorsal and anal fins each with minute first ray, three anteriormost rays closely spaced and unbranched. Anal-fin origin just below base of tenth (tenth to twelfth) dorsal-fin ray; posterior tip of depressed fin not reaching caudal-fin base. Uppermost pectoral-fin ray unbranched, inserted below lateral midline of body; posterior tip of fin not reaching vertical through pelvic-fin insertion. Pelvic fin shorter than pectoral fin, insertion anterior to vertical through dorsal-fin origin; posterior tip of depressed fin reaching to vertical through origin of fourth dorsal-fin ray (third to fifth).

Coloration of preserved specimens. Body uniformly pale ivory with silver longitudinal band, its width slightly less than pupil diameter, from just posterior to upper opercular margin to caudal-fin base. A pair of dark patches behind occiput without a following pair of dark lines; no black spots below eye or on lower-jaw tip. Live and fresh coloration unknown.

Distribution. Stolephorus nelsoni is distributed along the northern coast of Australia (from Eighty Mile Beach,

Meristics of the studied specimens of Stolephorus nelsoni and S. brachycephalus

Table 1

\begin{tabular}{|c|c|c|c|c|c|c|c|}
\hline \multirow{4}{*}{ Character } & \multicolumn{4}{|c|}{ Stolephorus nelsoni } & \multicolumn{3}{|c|}{ Stolephorus brachycephalus } \\
\hline & \multirow{2}{*}{\multicolumn{2}{|c|}{$\frac{\text { Holotype Paratype }}{\text { Western Australia }}$}} & \multirow{3}{*}{$\begin{array}{c}\text { Non-type } \\
\text { IDN and AUS } \\
n=15\end{array}$} & \multirow{3}{*}{ Mode } & \multirow{2}{*}{\multicolumn{2}{|c|}{$\frac{\text { Holotype Paratypes }}{\text { Papua New Guinea }}$}} & \multirow{3}{*}{ Mode } \\
\hline & & & & & & & \\
\hline & $\mathrm{AMNH}$ & USNM & & & $\mathrm{BMNH}$ & $n=8$ & \\
\hline Standard length (SL) [mm] & 71.6 & 71.6 & $41.2-81.5$ & & 41.8 & $26.5-28.1$ & \\
\hline Dorsal-fin rays (unbranched) & 3 & 3 & 3 & 3 & 3 & 3 & 3 \\
\hline Dorsal-fin rays (branched) & 13 & 13 & $12-13$ & 12 & 13 & $12-13$ & 13 \\
\hline Anal-fin rays (unbranched) & 3 & 3 & 3 & 3 & 3 & 3 & 3 \\
\hline Anal-fin rays (branched) & 17 & 17 & $15-17$ & 17 & 20 & $20-22$ & 20 \\
\hline Pectoral-fin rays (unbranched) & 1 & 1 & 1 & 1 & 1 & 1 & 1 \\
\hline Pectoral-fin rays (branched) & 12 & 12 & $12-14$ & 12 & 11 & $10-12$ & 11 \\
\hline Pelvic-fin rays (unbranched) & 1 & 1 & 1 & 1 & 1 & 1 & 1 \\
\hline Pelvic-fin rays (branched) & 6 & 6 & 6 & 6 & 6 & 6 & 6 \\
\hline Caudal-fin rays (upper + lower) & $10+9$ & $10+9$ & $10+9$ & $10+9$ & $10+9$ & $10+9$ & $10+9$ \\
\hline Gill rakers on 1st gill arch (upper) & 19 & 18 & $16-19$ & 17 & 15 & $15-16$ & 15 \\
\hline Gill rakers on 1st gill arch (lower) & 23 & 24 & $20-24$ & 22 & 21 & $20-21$ & 21 \\
\hline Gill rakers on 1st gill arch (total) & 42 & 42 & $37-43$ & 39,40 & 36 & $35-37$ & 35 \\
\hline Gill rakers on 2nd gill arch (upper) & 14 & 14 & $12-13$ & 13 & 11 & $11-13$ & 11,12 \\
\hline Gill rakers on 2nd gill arch (lower) & 22 & broken & $18-22$ & 20,21 & 18 & $18-21$ & 19 \\
\hline Gill rakers on 2nd gill arch (total) & 36 & broken & $30-35$ & 33 & 29 & $30-33$ & 30,31 \\
\hline Gill rakers on 3rd gill arch (upper) & 12 & broken & $9-11$ & 10 & 9 & $9-10$ & 9 \\
\hline Gill rakers on 3rd gill arch (lower) & 13 & broken & $12-13$ & 12 & 11 & $10-12$ & 11 \\
\hline Gill rakers on 3rd gill arch (total) & 25 & broken & $21-24$ & 23 & 20 & $19-22$ & 20 \\
\hline Gill rakers on 4th gill arch (upper) & 9 & broken & $8-9$ & 8,9 & 6 & $6-9$ & 7 \\
\hline Gill rakers on 4th gill arch (lower) & 11 & broken & $9-11$ & 10 & 9 & $8-10$ & 9 \\
\hline Gill rakers on 4th gill arch (total) & 20 & broken & $18-20$ & 18 & 15 & $14-19$ & 15 \\
\hline Gill rakers on posterior face of $3 \mathrm{rd}$ gill arch & 7 & broken & $3-6$ & 5 & 5 & $3-6$ & 5 \\
\hline Prepelvic scutes & 4 & 5 & $4-7$ & 5 & 4 & $2-5$ & 4 \\
\hline Scale rows in longitudinal series & 35 & 35 & $34-36$ & 35 & 33 & $33-34$ & 34 \\
\hline Transverse scales & 8 & 8 & 8 & 8 & 8 & 8 & 8 \\
\hline Branchiostegal rays & 13 & broken & $12-14$ & 13 & 10 & 11 & 11 \\
\hline Pseudobranchial filaments & broken & broken & $16-20$ & 18 & 18 & $14-17$ & $14,16,17$ \\
\hline
\end{tabular}

IDN and AUS = Indonesia and Australia, AMNH = AMNH 57157, USNM = USNM 280176, BMNH = BMNH 1979.3.21.447. 
Western Australia to Mackenzie Island, Queensland; S. nelsoni as having 20 or 21 anal-fin rays, modified in Wongratana 1987, Whitehead et al. 1988, Wongratana et Whitehead et al. (1988) and Wongratana et al. (1999) as al. 1999, Paxton et al. 2006, this study) and in Irian Jaya, three unbranched rays and 20 branched rays, the anal-fin Indonesia (this study) (Fig. 2).

\section{DISCUSSION}

Stolephorus nelsoni was described by Wongratana (1987) based on four specimens collected from Western Australia and Queensland, Australia, the species being known to date only from the type specimens. Examination of additional material from the northern coast of Australia and Indonesia confirmed the validity of $S$. nelsoni, with the unique combination of characters described in the Diagnosis (above). Although Wongratana (1987) recorded ray count observed in the presently reported study was iii, 15-17, the values indicated in Whitehead et al. (1988) and Wongratana et al. (1999) being clearly erroneous.

Although $S$. nelsoni is similar to $S$. brachycephalus (Fig. 3) in sharing the maxilla well beyond the posterior margin of preopercle, the latter rounded posteriorly, and the dorsal fin without scutes, the former has more gill rakers (24 in S. nelsoni vs. 20-22 in S. brachycephalus) and branchiostegal rays (12 or 13 vs. 10 or 11$)$, and a tooth patch on the hyoid bone upper edge (vs. teeth absent), according to Wongratana et al. 1999. The present

Table 2

Morphometrics of specimens of Stolephorus nelsoni and S. brachycephalus

\begin{tabular}{|c|c|c|c|c|c|c|c|}
\hline \multirow{4}{*}{ Character } & \multicolumn{4}{|c|}{ Stolephorus nelsoni } & \multicolumn{3}{|c|}{ Stolephorus brachycephalus } \\
\hline & Holotype & Paratype & Non-type & & Holotype & Paratypes & \\
\hline & \multicolumn{2}{|c|}{ Western Australia } & \multicolumn{2}{|l|}{ IDN and AUS } & \multicolumn{3}{|c|}{ Papua New Guinea } \\
\hline & AMNH & USNM & $n=15$ & Mean & $\mathrm{BMNH}$ & $n=8$ & Mean \\
\hline Standard length (SL) [mm] & 71.6 & 71.6 & $41.2-81.5$ & & 41.8 & $26.5-28.1$ & \\
\hline \multicolumn{8}{|l|}{ As \% SL } \\
\hline Head length (HL) & 28.4 & 27.2 & $26.4-28.1$ & 27.3 & 26.4 & $26.6-26.9$ & 26.8 \\
\hline Body depth & 23.7 & 23.6 & $21.1-22.6$ & 22.1 & 20.2 & $18.2-20.3$ & 19.1 \\
\hline Pre-dorsal-fin length & 55.2 & 52.6 & $49.8-54.9$ & 53.2 & 52.3 & $53.2-57.3$ & 54.9 \\
\hline Snout tip to pectoral-fin insertion & 30.1 & 30.9 & $27.9-30.6$ & 29.4 & 27.1 & $27.5-28.8$ & 28.1 \\
\hline Snout tip to pelvic-fin insertion & 49.1 & 47.6 & $43.9-48.6$ & 46.9 & 44.4 & $42.7-46.4$ & 44.5 \\
\hline Snout to anal-fin origin & 66.7 & 64.9 & $61.7-66.7$ & 64.8 & 60.6 & $59.7-64.9$ & 62.1 \\
\hline Length of dorsal-fin base & 16.7 & 16.8 & $13.9-17.4$ & 15.6 & 15.1 & $14.9-16.4$ & 15.7 \\
\hline Length of anal-fin base & 17.2 & 17.3 & $16.1-19.3$ & 17.6 & 22.3 & $21.6-24.4$ & 23.2 \\
\hline Length of caudal peduncle & 18.1 & 16.5 & $15.7-21.7$ & 18.8 & 14.3 & $12.6-15.2$ & 14.1 \\
\hline Depth of caudal peduncle & 10.0 & 9.9 & $9.0-11.0$ & 9.9 & 8.9 & $6.9-9.7$ & 8.9 \\
\hline Pectoral-fin length & broken & 17.1 & $15.2-17.8$ & 16.5 & 17.4 & $13.5-16.9$ & 15.9 \\
\hline Pelvic-fin length & 9.3 & 9.0 & $8.0-9.5$ & 8.9 & 9.4 & $9.3-10.8$ & 10.0 \\
\hline Interorbital width & 6.7 & 7.2 & $6.0-7.8$ & 6.7 & 6.8 & $6.2-7.1$ & 6.7 \\
\hline Snout length & 5.4 & 4.9 & $4.5-5.5$ & 5.1 & 4.3 & $3.6-4.2$ & 4.0 \\
\hline Upper-jaw length & 22.9 & 22.5 & $21.1-22.6$ & 22.1 & 19.9 & $21.0-22.8$ & 21.5 \\
\hline Mandibular length & 18.8 & 18.0 & $17.4-18.6$ & 18.1 & 17.8 & $17.5-19.0$ & 18.2 \\
\hline 1st dorsal-fin ray length & 2.1 & 1.8 & $1.1-2.3$ & 1.7 & 1.9 & $1.0-2.4$ & 1.8 \\
\hline 2nd dorsal-fin ray length & broken & 7.4 & $6.9-8.5$ & 7.7 & 9.3 & 9.2 & 9.2 \\
\hline 3rd dorsal-fin ray length & broken & broken & $15.4-17.9$ & 16.3 & broken & broken & broken \\
\hline 1st anal-fin ray length & 1.8 & 1.8 & $0.9-2.5$ & 1.5 & 1.9 & $1.8-2.6$ & 2.2 \\
\hline 2nd anal-fin ray length & 5.1 & 4.7 & $4.4-6.7$ & 5.1 & 5.5 & $4.4-6.3$ & 5.4 \\
\hline 3rd anal-fin ray length & broken & broken & $11.9-13.9$ & 13.2 & broken & 15.1 & 15.1 \\
\hline 1st pectoral-fin ray length & broken & broken & $15.2-17.8$ & 16.6 & 16.5 & 13.5 & 15.0 \\
\hline 1st pelvic-fin ray length & 9.3 & 8.6 & $8.0-9.5$ & 8.8 & broken & $9.3-10.6$ & 10.1 \\
\hline \multicolumn{8}{|l|}{ As $\% \mathrm{HL}$} \\
\hline Length of orbit & 32.5 & 32.9 & $31.2-34.8$ & 32.7 & 26.3 & $27.9-32.6$ & 30.3 \\
\hline Length of eye & 23.5 & 23.3 & $23.3-29.4$ & 25.1 & 22.2 & $20.8-25.8$ & 23.6 \\
\hline D-P1 & 122.6 & 128.8 & $117.6-130.6$ & 122.8 & 127.2 & $122.2-133.8$ & 127.2 \\
\hline D-P2 & 90.3 & 93.7 & $80.0-94.4$ & 87.2 & 86.3 & $79.2-86.9$ & 83.7 \\
\hline D-A & 90.2 & 94.5 & $82.7-94.1$ & 88.7 & 90.1 & $77.2-85.7$ & 81.9 \\
\hline $\mathrm{P} 1-\mathrm{P} 2$ & 68.5 & 68.3 & $61.0-74.3$ & 68.5 & 67.1 & $54.6-65.7$ & 62.4 \\
\hline P2-A & 62.2 & 68.8 & $55.5-72.8$ & 65.3 & 67.0 & $62.4-68.4$ & 65.1 \\
\hline Postorbital length of the head & 51.1 & 51.6 & $58.3-64.7$ & 50.1 & 55.1 & $50.1-54.9$ & 53.1 \\
\hline
\end{tabular}

IDN and AUS = Indonesia and Australia, AMNH = AMNH 57157, USNM = USNM 280176, BMNH = BMNH 1979.3.21.447. 


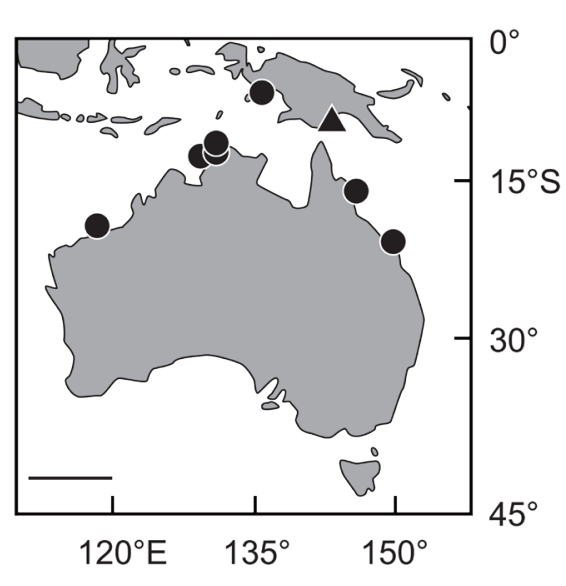

Fig. 2. Distributional records of Stolephorus nelsoni (circles) and $S$. brachycephalus (triangles), based on specimens examined in this study; scale bar represents $1000 \mathrm{~km}$

comparisons of $S$. nelsoni with $S$. brachycephalus, based on 17 and 9 specimens, respectively, confirmed the branchiostegal ray and hyoid bone tooth conditions described by Wongratana et al. (1999). However, the lower gill raker number in S. nelsoni was 20-24 (modally 22), a greater range than that reported by Wongratana et al. (1999). The comparable range for S. brachycephalus was 20 or 21 , not 20-22 as shown by Whitehead et al. (1988) and Wongratana et al. (1999). Therefore, lower gill raker numbers cannot clearly separate the two species. However, S. nelsoni differs from S. brachycephalus in having relatively more total gill rakers on the first gill arch (37-43 vs. 35-37), and fewer branched anal-fin rays (1517 vs. 20-22) and branched pectoral-fin rays (12-14 vs. 10-12; Table 1). Morphometrically, S. nelsoni differs from S. brachycephalus in having a deeper body $(21.1 \%-23.7 \%$ SL vs. 18.2\%-20.3\%), shorter anal-fin base (16.1\%-19.3\% VS. $21.6 \%-24.4 \%)$, longer caudal peduncle $(15.7 \%-$ $21.7 \%$ vs. $12.6 \%-15.2 \%)$ and longer snout $(4.5 \%-5.5 \%$ vs. $3.6 \%-4.3 \%$; Table 2; Fig. 4). Notwithstanding, S. brachycephalus has been reported only from specimens smaller than $41.8 \mathrm{~mm}$ SL (Wongratana 1983, Whitehead et al. 1988, Wongratana et al. 1999, this study), which may or may not have been adult. If larger and smaller specimens of $S$. brachycephalus and $S$. nelsoni, respectively, become
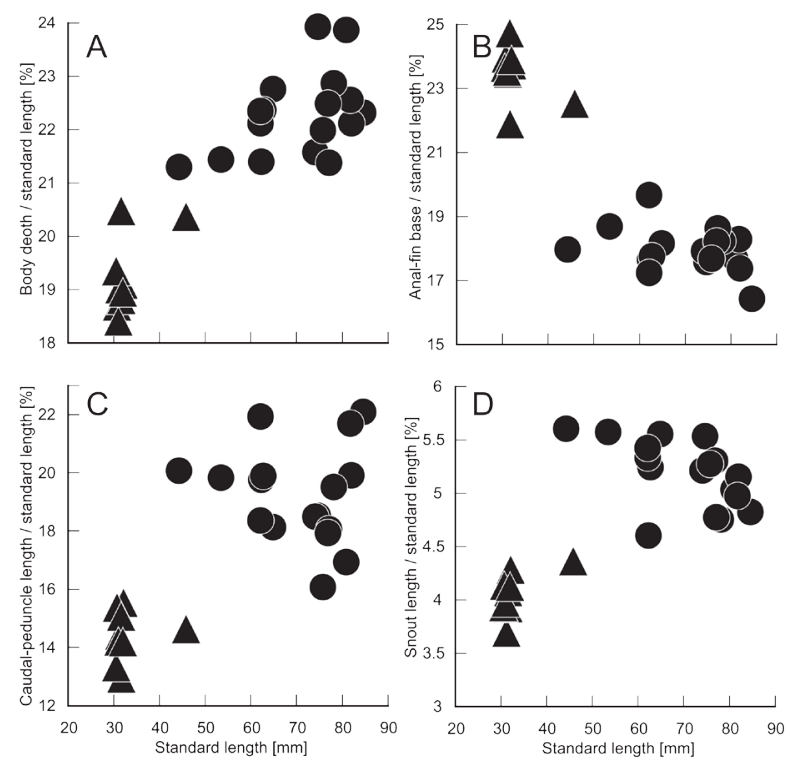

Fig. 4. Relations of (A) body depth, (B) anal-fin base, (C) caudal-peduncle length, and (D) snout length to standard length in Stolephorus nelsoni (circles) and S. brachycephalus (triangles)

available, the differences shown here between $S$. nelsoni and $S$. brachycephalus may not hold up.

The collection of $S$. nelsoni specimens from Indonesian and northern Australian waters suggests that the species is also likely distributed off the southern coast of Papua New Guinea.

Comparative material examined. Stolephorus brachycephalus, 9 specimens, 26.5-41.8 $\mathrm{mm}$ SL: BMNH 1979.3.21.447, holotype of Stolephorus brachycephalus, $41.8 \mathrm{~mm}$ SL, east side of Daru Wharf, Gulf of Papua, Papua New Guinea; USNM 270294, 8 paratypes of Stolephorus brachycephalus, 25.6-28.1 mm SL, east side of Daru Wharf, Gulf of Papua, Papua New Guinea.

\section{ACKNOWLEDGEMENTS}

We thank R. Arrindell (AMNH), M. McGrouther, S. Reader and A. Hay (AMS), O. Crimmen and J. Maclaine (BMNH), B. Russell, M. Hammer and

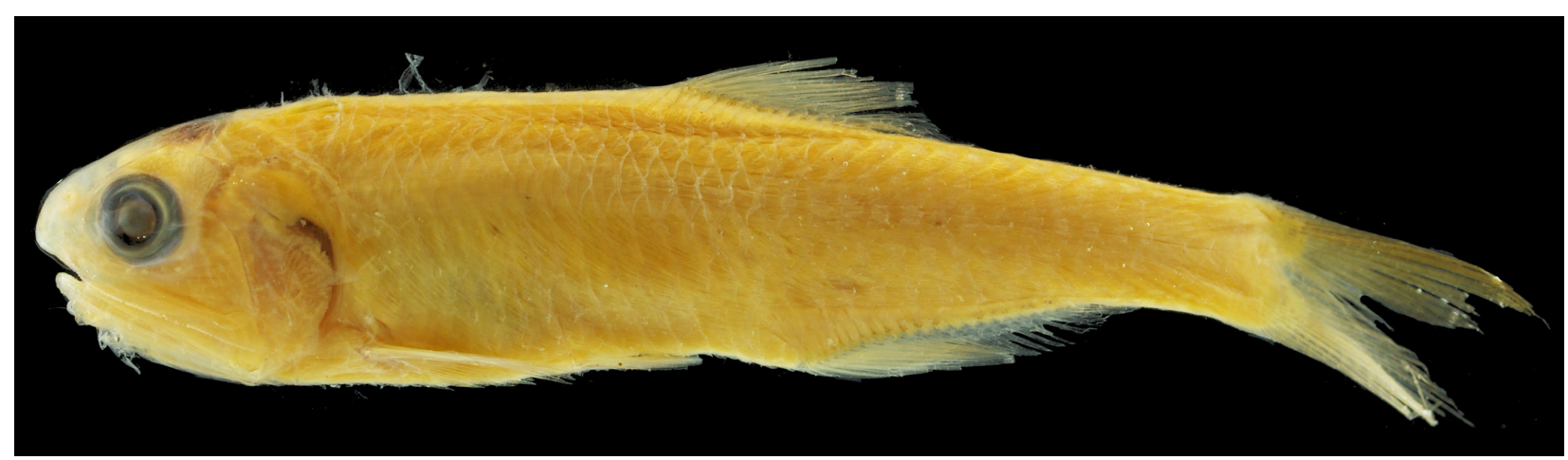

Fig. 3. Holotype of Stolephorus brachycephalus; BMNH 1979.3.21.447, 41.8 mm SL, Papua New Guinea 
G. Dally (NTM), and J. Williams, K. Murphy, S. Raredon and D. Pitassy (USNM) for opportunities to examine specimens of Stolephorus. We also thank Y. Haraguchi and other volunteers, and students of KAUM for their curatorial assistance, and G. Hardy (Ngunguru, New Zealand), for checking an early version of the manuscript. This study was supported in part by a Grant-in-Aid from the Japan Society for the Promotion of Science for JSPS Fellows (DC2: 29-6652); the Sasakawa Scientific Research Grant from the Japan Science Society (28745); JSPS KAKENHI Grant Numbers JP19770067, JP26241027, JP24370041, JP23580259, and JP26450265; the "Biological Properties of Biodiversity Hotspots in Japan" project of the National Museum of Nature and Science, Tsukuba, Japan; "Establishment of Research and Education Network on Biodiversity and Its Conservation in the Satsunan Islands" project of Kagoshima University adopted by the Ministry of Education, Culture, Sports, Science and Technology, Japan; and the "Island Research" project by Kagoshima University

\section{REFERENCES}

Hata H. Motomura H. 2017. A new species of anchovy, Encrasicholina auster (Clupeiformes: Engraulidae), from Fiji, southwestern Pacific. New Zealand Journal of Zoology 44 (2): 122-128. DOI: 10.1080/03014223.2016.1268177

Paxton J.R., Gates J.E., Bray D.J., Hoese D.F. 2006. Engraulidae. Anchovies. Pp. 310-317. In: Hoese D.F., Bray D.J., Paxton J.R., Allen G.R. (eds.) Zoological catalogue of Australia. Volume 35. Fishes. Part 1-3. CSIRO Publishing, Collingwood VIC, Australia.

Sabaj M.H. 2016. Standard symbolic codes for institutional resource collections in herpetology and ichthy- ology: An online reference. Version 6.5 (16 August 2016). American Society of Ichthyologists and Herpetologists, Washington DC, USA. [Accessed 19 March 2018] https://asih.org/sites/default/files/documents/ symbolic_codes_for_collections_v6.5_2016.pdf\# search $=\overline{\%} 27$ Standard + symbolic + codes + for + institutional + resource + collections + in + herpetology + and + ichthyology $\% 27$.

Whitehead P.J.P., Nelson G.J., Wongratana T. 1988. FAO species catalogue, Vol. 7. Clupeoid fishes of the world (suborder Clupeoidei). An annotated and illustrated catalogue of the herrings, sardines, pilchards, sprats, shads, anchovies and wolf-herrings. Part 2 - Engraulidae. FAO Fisheries Synopsis, No. 125 7 (2): i-viii + 305-579.

Wongratana T. 1983. Diagnosis of 24 new species and proposal of a new name for a species of Indo-Pacific clupeoid fishes. Japanese Journal of Ichthyology 29 (4): 385-407. DOI: 10.11369/jji1950.29.385

Wongratana T. 1987. Two new species of anchovies of the genus Stolephorus (Engraulidae), with a key to species of Engraulis, Encrasicholina, and Stolephorus. American Museum Novitates 2876: 1-8.

Wongratana T., Munroe T.A., Nizinski M.S. 1999. Order Clupeiformes. Engraulidae, Anchovies. Pp. 1698-1753. In: Carpenter K.E., Niem V.H. (eds.) FAO species identification guide for fishery purposes. The living marine resources of the western central Pacific, Vol. 3. Batoid fishes, chimaeras and bony fishes Part 1 (Elopidae to Linophrynidae). FAO, Rome.

Received: 15 July 2018 Accepted: 4 September 2018 Published electronically: 31 December 2018 